\title{
Peran kelompok tani terhadap usahatani padi di Kecamatan Sale Kabupaten Rembang
}

\author{
(The role of farmers group in rice farming in Sale District of Rembang Regency) \\ F.M. Nugroho, S. Satmoko, Karno \\ Magister Agribisnis, Fakultas Peternakan dan Pertanian, Universitas Diponegoro \\ Kampus Tembalang, Semarang 50275 - Indonesia \\ Corresponding E-mail : fitra_m_n@yahoo.co.id
}

\begin{abstract}
Farming development through farmer groups is an effort to accelerate the improvement of farmers' welfare. The purpose of this research was to analyze the role of farmer groups as learning class, cooperation vehicle, and production unit in influencing farmer behavior, access of production facilities, application of Integrated Crop Management (ICM) and farming profit. The research population was members of farmer groups in Kecamatan Sale Kabupaten Rembang who have irrigated land with an area of 0.2-0.5 Ha. Determination of sampling was done by using purposive random sampling method with total sample of 276 farmers. Interviews with questionnaires were used as data collection methods. Data were analyzed using path analysis to know the relationships between variables. Results of research indicated that role of farmer group as study class, cooperation vehicle, and production unit had an effect to farmer behavior. The role of farmer groups as a vehicle for cooperation, production unit and farmer behavior had an effect on access production facilities. Behavior of farmers and access to production facilities affected the application of ICM. The application of ICM had an effect on the profit of farming. $\mathrm{R} / \mathrm{C}$ Ratio of paddy farming in Sale District, Rembang Regency was equal to 1,23.
\end{abstract}

Keywords : farmer group; farmer behavior; application of ICM

\begin{abstract}
ABSTRAK
Pembinaan petani melalui kelompok tani adalah sebagai upaya percepatan peningkatan kesejahteraan petani. Tujuan penelitian adalah menganalisis peran kelompok tani sebagai kelas belajar, wahana kerjasama, dan unit produksi dalam mempengaruhi perilaku petani, akses sarana produksi, penerapan Pengelolaan Tanaman Terpadu (PTT) dan keuntungan usahatani. Anggota kelompok tani di Kecamatan Sale Kabupaten Rembang yang memiliki lahan sawah irigasi dengan luas 0,2-0,5 Ha ditetapkan sebagai populasi penelitian. Penentuan sampel dengan metode purposive random sampling, jumlah sample 276 petani. Wawancara dengan kuesioner digunakan sebagai metode pengumpulan data. Analisis data menggunakan analisis jalur untuk mengetahui hubungan antar variabel. Hasil penelitian menunjukkan bahwa peran kelompok tani sebagai kelas belajar, wahana kerjasama, dan unit produksi berpengaruh terhadap perilaku petani. Peran kelompok tani sebagai wahana kerjasama, unit produksi dan perilaku petani berpengaruh terhadap akses sarana produksi. Perilaku petani dan akses sarana produksi berpengaruh terhadap penerapan PTT. Penerapan PTT berpengaruh terhadap keuntungan usaha tani. Tingkat R/C Ratio usahatani padi di Kecamatan Sale Kabupaten Rembang sebesar 1,23.

Kata kunci : kelompok tani, perilaku petani, penerapan PTT
\end{abstract}

\section{PENDAHULUAN}

Kelompok tani dibentuk dengan tujuan meningkatkan dan mengembangkan kemampuan anggota dan keluarganya. Berada dalam organisasi, petani sebagai subyek sekaligus obyek pembangunan, dapat berperan dalam meningkatkan produksi pertanian, meningkatkan 
kesejahteraan petani, memerangi kemiskinan, memperbaiki degradasi sumber daya alam, meningkatkan keterlibatan perempuan, serta juga kesehatan, pendidikan, dan sosial politik (Syahyuti et al., 2014).

Peraturan Menteri Pertanian Nomor 67/Permentan/SM.050/12/2016 merinci fungsi kelompok tani sebagai kelas belajar, wahana kerjasama, dan unit produksi. Kelompok tani merupakan wadah belajar mengajar guna meningkatkan pengetahuan, keterampilan dan sikap petani agar dapat meningkatkan produktivitas, pendapatan serta kehidupan yang lebih baik. Kelompok tani sebagai wahana kerjasama merupakan tempat untuk kerjasama baik diantara sesama petani dalam poktan dan antar poktan maupun dengan pihak lain. Melalui kerjasama ini diharapkan usahatani lebih efisien dan lebih mampu menghadapi ancaman, tantangan, hambatan, gangguan serta lebih menguntungkan.

Pertanian yang terkonsolidasi dalam kelompok tani, membuka peluang pengadaan sarana produksi dan penjualan hasil dilakukan secara bersama. Dengan demikian, volume sarana produksi yang dibeli dan volume hasil yang dijual menjadi lebih besar, sehingga biaya pengadaan persatuan sarana dan menjadi lebih rendah (Nuryanti dan Swastika, 2011). Usahatani oleh anggota poktan secara keseluruhan harus dipandang sebagai satu kesatuan usaha yang dapat dikembangkan untuk mencapai skala ekonomis usaha, dengan menjaga kuantitas, kualitas maupun kontinuitas. Keanggotaan kelompok menimbulkan dampak positif pada hasil, keuntungan bersih pertanian dan pendapatan rumah tangga. Hal ini menegaskan bahwa kelompok tani memberikan efek positif bagi anggotanya dalam meningkatkan pendapatan petani (Ma dan Abdulai, 2016).

Kecamatan Sale merupakan salah satu kecamatan di Kabupaten Rembang yang didukung dengan ketersediaan air irigasi yang baik. Ketersediaan air tersebut dipenuhi oleh dua sumber mata air yaitu Sumber Semen dan Brubulan yang mampu menyediakan kebutuhan air irigasi sepanjang tahun. Petani padi di Kecamatan Sale sebagian besar telah tergabung dalam kelompok tani yang telah mengikuti kegiatan Pengelolaan Tanaman Terpadu (PTT). Budidaya padi dengan pendekatan Pengelolaan
Tanaman Terpadu (PTT) merupakan upaya untuk mensinergikan seluruh sumber daya yang ada baik tanah, air, tanaman dan juga komponen teknologi.

Berdasarkan uraian diatas, maka tujuan penelitian ini adalah untuk : (1) Menganalisis peran kelompok tani sebagai kelas belajar, wahana kerjasama, dan unit produksi dalam mempengaruhi perilaku petani, (2) Menganalisis peran kelompok tani sebagai wahana kerjasama, unit produksi dan perilaku petani dalam mempengaruhi akses sarana produksi pertanian petani, (3) Menganalisis perilaku dan akses sarana produksi pertanian petani dalam mempengaruhi penerapan PTT padi, (4) Menganalisi perilaku, akses sarana produksi pertanian, dan penerapan PTT padi dalam mempengaruhi usahatani, (5) Menganalisis pendapatan usahatani padi petani.

\section{METODE PENELITIAN}

Penelitian ini menggunakan pendekatan kuantitatif dengan metode survei. Penelitian kuantitatif memiliki beberapa karakteristik antara lain hipotesis ditentukan pada awal penelitian, definisi operasional jelas sejak awal penelitian, mereduksi data kedalam angka, dan kesimpulan hasil dengan statistik (Hamdi dan Bahruddin, 2012). Metode survei bertujuan mengetahui gambaran umum suatu populasi melalui pendekatan sampel. Penelitian ini dilaksanakan kurang lebih selama 5 bulan yaitu dimulai pada bulan Januari sampai dengan bulan Mei 2017. Lokasi penelitian dilaksanakan di Kecamatan Sale Kabupaten Rembang.

Populasi penelitian meliputi petani padi di Kecamatan Sale yang tergabung dalam kelompok tani dan memiliki lahan irigasi teknis dengan luasan $0,20-0,50$ Ha. Ketersediaan air menentukan pertumbuhan dan perkembangan tanaman. Hampir semua proses aktifitas pertumbuhan tanaman dipengaruhi oleh air. Setiap metabolisme sel tanaman dipengaruhi ketersediaan air didalamnya (Mawardi, 2016). Disisi lain petani luas lahan dibawah 0,5 ha atau yang biasa disebut petani gurem merupakan jumlah rumah tangga usaha pertanian dominan di Jawa Tengah sebanyak 3,31 juta rumah tangga atau $77,7 \%$ dari keseluruhan rumah tangga pertanian pada Sensus Pertanian tahun 2013 (BPS Provinsi Jawa Tengah, 2015). 
Penentuan jumlah sampel dilakukan dengan menggunakan formula Slovin (Ariola, 2006) :

$$
n=N / 1+N(\text { moe }) 2
$$

\section{Keterangan :}

$\mathrm{n} \quad$ : jumlah sampel

$\mathrm{N}$ : populasi

moe : margin of error max tingkat kesalahan maksimal yang dapat ditoleransi

Berdasarkan rumus tersebut, maka penentuan sampel dengan populasi 895 petani dan margin of error max diambil sebesar $5 \%$ adalah sebesar 276 responden.

Upaya memenuhi tujuan menganalisis peran kelompok tani sebagai kelas belajar, wahana kerjasama, dan unit produksi; menganalisis peran kelompok tani sebagai kelas belajar, wahana kerjasama, dan unit produksi dalam mempengaruhi perilaku petani; menganalisis peran kelompok tani sebagai wahana kerjasama dan unit produksi dalam mempengaruhi akses sarana produksi pertanian petani; menganalisis perilaku petani dalam mempengaruhi akses sarana produksi pertanian petani; dan menganalisis perilaku dan akses sarana produksi pertanian petani dalam mempengaruhi usahatani padi petani digunakan analisis jalur (path analysis).

Upaya memenuhi tujuan menganalisis pendapatan usahatani dengan menentukan $\mathrm{R} / \mathrm{C}$ Ratio. Usahatani merupakan suatu kegiatan ekonomi yang ditujukan untuk menghasilkan output (penerimaan) dengan input fisik, tenaga kerja, dan modal sebagai korbanannya. Penerimaan total adalah nilai produk total usahatani dalam jangka waktu tertentu. Pengeluaran total usahatani adalah semua nilai input yang dikeluarkan dalam proses produksi.

\section{HASIL DAN PEMBAHASAN}

Kecamatan Sale merupakan kecamatan di Kabupaten Rembang yang berbatasan dengan Kabupaten Blora dan Kabupaten Tuban. Wilayah administrasi Kecamatan Sale seluas 10.714 Ha. (Hanudin et al., 2003).

\section{Profil Responden}

Hasil penelitian menunjukkan bahwa responden termasuk usia produktif, yaitu antara 30 - 60 tahun. Sebaran usia 30-40 th 14\%, 41-50 th $28 \%$ dan sebagian besar responden (58\%) memiliki usia 51-60 tahun. Keterkaitan usia dengan usahatani dalam hal proses adopsi teknologi. Usia muda akan lebih termotifasi untuk menerapkan teknologi baru (Awais dan Khan, 2014). Meskipun usaha dibidang pertanian sebagian besar membutuhkan kemampuan keterampilan, namun tingkat pendidikan dapat memberikan korelasi positif terhadap pola pikir dalam pemecahan masalah. Hal tersebut memiliki arti bahwa perlu diupayakan peningkatan pengetahuan dan keterampilan dalam berusahatani berupa penyuluhan.

Usahatani padi merupakan usaha pokok keluarga di daerah penelitian. Luas penguasaan lahan petani adalah 0,2-0,5 ha. Petani memiliki pengalaman bertani diatas 10 tahun. Petani tentunya memiliki penilaian awal apakah sebuah teknologi inovasi dapat diterapkan atau tidak, serta apakah teknologi inovasi tersebut mampu meningkatkan keuntungan usahatani baik dalam hal produktivitas, keamanan, kesinambungan ataupun identitasnya.

\section{Penilaian Variabel Penelitian}

Nilai ideal dan hasil rerata variabel penelitian disajikan pada Tabel 1. Hasil analisis data primer variabel kelas belajar memiliki nilai rerata kelas belajar 39,05 $\pm 4,78$ dari nilai ideal 56. Responden menilai peran kelompok tani sebagai kelas belajar dengan kriteria rendah $0 \%$, kriteria sedang $72 \%$, dan kriteria tinggi 28\%. Peran kelompoktani sebagai kelas belajar memberikan ruang bagi petani untuk menerima transfer teknologi. Proses adopsi teknologi sendiri dipengaruhi oleh pendidikan, luas lahan, total pendapatan, pelatihan, keanggotaan dalam organisasi sosial, komunikasi, promosi, persepsi resiko teknologi baru (Shah, et al., 2016). Frekuensi nilai variabel kelas belajar pada kriteria sedang (72\%) memberikan kesempatan petani untuk memperoleh informasi tentang inovasi.

Kelompok tani sebagai wahana kerjasama akan memberikan keuntungan bagi petani dalam memenuhi kebutuhan akan tenaga kerja, pinjaman modal, obat-obatan, pupuk, traktor, perlengkapan penyimpanan, dan perlengkapan pasca panen 
Tabel 1. Nilai Ideal dan Hasil Rerata Variabel Penelitian

\begin{tabular}{lrrrrrrr}
\hline \hline & X1 & X2 & \multicolumn{1}{c}{ Y1 } & \multicolumn{1}{c}{ Y2 } & \multicolumn{1}{c}{ Y3 } & \multicolumn{1}{c}{ Y4 } & X3 \\
\hline Jumlah Instrumen & 14,00 & 10,00 & 24,00 & 9,00 & 7,00 & 21,00 & 14,00 \\
Nilai Ideal & $\mathbf{5 6 , 0 0}$ & $\mathbf{4 0 , 0 0}$ & $\mathbf{9 6 , 0 0}$ & $\mathbf{3 6 , 0 0}$ & $\mathbf{2 8 , 0 0}$ & $\mathbf{8 4 , 0 0}$ & $\mathbf{5 6 , 0 0}$ \\
\hline Hasil Tertinggi & 51,00 & 35,00 & 91,00 & 36,00 & 28,00 & 80,00 & 51,00 \\
Jumlah Responden & 1,00 & 3,00 & 4,00 & 4,00 & 1,00 & 9,00 & 1,00 \\
Hasil Terendah & 29,00 & 16,00 & 52,00 & 20,00 & 16,00 & 48,00 & 26,00 \\
Jumlah Responden & 5,00 & 2,00 & 1,00 & 2,00 & 8,00 & 4,00 & 4,00 \\
\hline Rerata & $\mathbf{3 9 , 0 5}$ & $\mathbf{2 5 , 4 5}$ & $\mathbf{7 5 , 6 1}$ & $\mathbf{2 9 , 5 4}$ & $\mathbf{2 2 , 3 3}$ & $\mathbf{6 7 , 7 3}$ & $\mathbf{3 7 , 8 9}$ \\
Standar Deviasi & $\mathbf{4 , 7 8}$ & $\mathbf{4 , 6 4}$ & $\mathbf{8 , 2 0}$ & $\mathbf{3 , 2 2}$ & $\mathbf{2 , 5 3}$ & $\mathbf{7 , 5 8}$ & $\mathbf{4 , 8 1}$ \\
\hline Sum & & & & & & &
\end{tabular}

Sumber : Analisis data primer, 2017

(Julius, 2015). Hasil analisis data primer variabel wahana kerjasama menunjukkan bahwa nilai rerata 25,45 \pm 4,64 dari nilai ideal 40. Responden menilai peran kelompok tani sebagai wahana kerjasama dengan kriteria rendah $16 \%$, kriteria sedang $67 \%$, dan kriteria tinggi $17 \%$. Hal ini menunjukkan bahwa wahana kerjasama kelompok tani di Kecamatan Sale baik namun perlu ditingkatkan untuk mencapai peran ideal.

Kelompok tani sebagai unit produksi menempatkan usaha yang dilaksanakan oleh masing-masing anggota kelompok tani secara keseluruhan sebagai satu kesatuan usaha yang dapat dikembangkan untuk mencapai skala ekonomi, baik dipandang dari segi kuantitas, kualitas maupun kontinuitas (Swastika dan Hermanto, 2011).

Hasil analisis data primer variabel unit produksi menunjukkan bahwa nilai rerata $37,89 \pm$ 4,81 dari nilai ideal 56. Responden menilai peran kelompok tani sebagai unit produksi dengan kriteria rendah 3\%, kriteria sedang $74 \%$, dan kriteria tinggi $24 \%$. Hal ini menunjukkan bahwa unit produksi sebagai salah satu peran kelompok tani di Kecamatan Sale telah berjalan namun perlu ditingkatkan untuk mencapai peran yang ideal.

Hasil analisis data primer variabel perilaku petani menunjukkan bahwa nilai rerata $75,61 \pm$ 8,20 dari nilai ideal 96. Responden menilai perilaku petani dengan kriteria rendah $0 \%$, kriteria sedang $26 \%$, dan kriteria tinggi $74 \%$. Hal ini menunjukkan bahwa perilaku petani di Kecamatan Sale telah baik namun perlu ditingkatkan untuk mencapai perilaku yang ideal.

Rerata akses sarana produksi pertanian di
Kecamatan Sale 29,54 \pm 3,22 dari nilai ideal 36 . Tabel 1 menunjukkan bahwa responden menilai akses saprotan dengan kriteria rendah $0 \%$, kriteria sedang $16 \%$, dan kriteria tinggi $84 \%$. Penerapan PTT disusun oleh penerapan komponen PTT Padi. Hasil analisis rerata penerapan teknologi PTT di Kecamatan Sale 22,33 $\pm 2,53$ dari nilai ideal 28. Responden menilai penerapan PTT dengan kriteria rendah $0 \%$, kriteria sedang $24 \%$, dan kriteria tinggi $76 \%$. Hal ini menunjukkan bahwa teknologi PTT di Kecamatan Sale telah diterapkan dengan baik namun perlu ditingkatkan untuk mencapai ideal.

Rerata keuntungan usahatani di Kecamatan $67,73 \pm 7,58$ dari nilai ideal 84. Responden menilai keuntungan usahatani dengan kriteria rendah $0 \%$, kriteria sedang $19 \%$, dan kriteria tinggi $81 \%$. Hal ini menunjukkan bahwa usahatani padi di Kecamatan Sale telah memberikan keuntungan.

Keuntungan ini baik dalam hal ekonomis, keterjaminan bahwa usahataninya aman dari resiko kegagalan panen, keterjaminan bahwa modal usahataninya dapat diwariskan, dan usahatani tersebut merupakan identitas dan tingkat sosial dalam kehidupan bermasyarakat.

\section{Analisis Jalur}

Analisis jalur atau Path Analysis merupakan pengembangan dari regresi linier berganda. Teknik ini digunakan untuk menguji besarnya sumbangan (kontribusi) yang ditunjukkan oleh koefisien jalur pada setiap diagram jalur dari hubungan kausal antar variabel $X_{1} X_{2}$ dan $X_{3}$ terhadap $Y$ serta dampaknya terhadap Z. Analisis jalur merupakan 
teknik menganalisis hubungan sebab akibat yang tejadi pada regresi berganda jika variabel bebasnya mempengaruhi variabel tergantung tidak hanya secara langsung tetapi juga secara tidak langsung (Sarwono, 2007). Hasil analisis jalur menggunakan Program Amos 22 penelitian pada Ilustrasi 1.
H3 : diduga terdapat pengaruh peran kelompok tani sebagai terhadap perilaku petani Nilai koefisien regresi X1 (kelas belajar) terhadap Y1 (perilaku petani) sebesar 0,57. Hal ini menunjukkan bahwa antara kelas belajar dan perilaku memiliki hubungan positif, jika kelas belajar mengalami kenaikan satu satuan maka

\section{Unstandardized estimates}

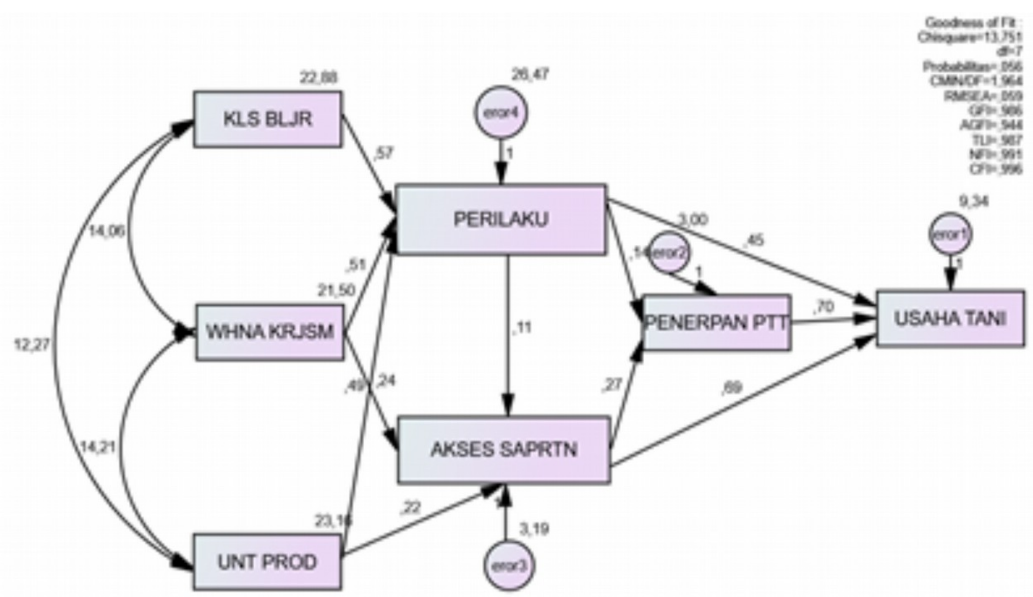

Ilustrasi 1. Diagram Hasil Analisis Jalur

Peran Kelompok tani sebagai Kelas Belajar, Wahana Kerjasama dan Unit Produksi dalam Mempengaruhi Perilaku Petani

Hasil analisis jalur dengan variabel independen peran kelompok tani sebagai kelas belajar, wahana kerjasama, dan unit produksi sedangkan variabel dependen adalah perilaku petani, termasuk didalamnya pengetahuan, sikap, dan keterampilan petani menunjukkan hasil persamaan sebagai berikut :

$$
Y 1=26,47+0,57 X 1+0,51 X 2+0,49 X 3
$$

Hasil persamaan peran kelompok tani sebagai kelas belajar, wahana kerjasama dan unit produksi dalam mempengaruhi perilaku petani menjawab hipotesis antara lain :

H1 : diduga terdapat pengaruh peran kelompok tani sebagai kelas belajar terhadap perilaku petani

H2 : diduga terdapat pengaruh peran kelompok tani sebagai wahana kerjasama terhadap perilaku petani perilaku petani akan mengalami peningkatan sebesar 0,57 atau 57\%. Hal ini memberikan pengertian bahwa Hipotesis 1 diterima. Kelompok tani sebagai bentuk organisasi nonformal melalui fungsi dan perannya sebagai kelas belajar ditujukan untuk menjawab kebutuhan petani akan pengetahuan dan peningkatan pola pikir. Hal ini akan berimplikasi positif kepada perilaku petani dalam mendukung peningkatan produksi dan kesejahteraannya. Penguatan disisi pengetahuan secara signifikan akan berpengaruh positif terhadap penguatan petani (Rashid et al., 2016). Upaya peningkatan fungsi kelompok tani sebagai kelas belajar dapat ditempuh dengan penguatan faktor yang secara signifikan berpengaruh terhadap peran kelompok tani sebagai kelas belajar. Faktor yang berpengaruh signifikan terhadap kelas belajar diantaranya interaksi antar anggota, kohesi kelompok, norma kelompok dan peran penyuluh pertanian (Hariadi, 2011). Metode pembelajaran sekolah lapang menjadi pilihan dalam meningkatkan pengetahuan petani (Guo et al., 2015). Metode partisipasi 
secara signifikan meningkatkan tingkat keberhasilan penyuluhan dibanding metode ceramah dan pelatihan penggunaan teknologi baru tanpa memperhatikan kesesuaian lokasi (Akbar dan Azizi, 2011).

Nilai koefisien regresi X2 (wahana kerjasama) terhadap Y1 (perilaku petani) sebesar 0,51 . Hal ini mengandung pengertian bahwa antara wahana kerjasama dan perilaku petani memiliki hubungan positif, jika wahana kerjasama mengalami kenaikan satu satuan maka perilaku petani akan mengalami peningkatan sebesar 0,51 atau $51 \%$. Untuk itu dapat disimpulkan bahwa Hipotesis 2 diterima. Keberadaan kelembagaan petani dibentuk dan berjalan didasarkan atas kerjasama petani dalam mengelola sumberdaya pertanian. Bentuk kerjasama itu antara lain dalam bidang pemprosesan, pemasaran, pembelian, pemakaian alat-alat pertanian, kerjasama pelayanan, bank kerjasama, kerjasama usahatani dan kerjasama multi-tujuan (Anantanyu, 2011). Upaya peningkatan peran kelompok tani sebagai wahana kerjasama dapat dilakukan dengan penguatan interaksi antar anggota, norma kelompok, penyuluh pertanian, dan pamong desa (Hariadi, 2011). Nilai koefisien regresi X3 (unit produksi) terhadap Y1 (perilaku petani) sebesar 0,49 . Hal ini mengandung pengertian bahwa antara unit produksi dan perilaku petani memiliki hubungan positif, jika unit produksi mengalami kenaikan satu satuan maka perilaku petani akan mengalami peningkatan sebesar $49 \%$. Hal ini memberikan pengertian bahwa Hipotesis 3 diterima.

Perilaku mengandung tiga komponen, yaitu perseptual, emosional, dan kecenderungan tindakan. Pengetahuan atau kognitif merupakan komponen perseptual yang berkaitan dengan pengetahuan tentang objek perilaku. Emosional atau afektif berkaitan dengan rasa senang atau tidak senang terhadap objek perilaku. Kecenderungan tindakan atau komponen konatif merupakan komponen yang berhubungan dengan kecenderungan bertindak terhadap objek (Hariadi, 2011). Berdasarkan hal tersebut, peran kelompok tani akan sangat berpengaruh dalam perilaku.

Peran Kelompok tani sebagai Wahana Kerjasama, Unit Produksi dan Perilaku Petani dalam Mempengaruhi Akses Saprotan
Hasil analisis jalur dengan variabel independen peran kelompok tani sebagai wahana kerjasama, dan unit produksi serta perilaku petani sedangkan variabel dependen adalah akses saprotan menunjukkan hasil persamaan sebagai berikut :

$$
Y 2=3,19+0,24 X 2+0,22 X 3+0,11 Y 1
$$

Melalui persamaan ini dapat menjawab beberapa hipotesis, antara lain :

H4 : diduga terdapat pengaruh peran kelompok tani sebagai wahana kerjasama terhadap akses sarana produksi pertanian petani

H5 : diduga terdapat pengaruh peran kelompok tani sebagai unit produksi terhadap akses sarana produksi pertanian petani

H6 : diduga terdapat pengaruh perilaku petani terhadap akses sarana produksi pertanian

Nilai koefisien regresi X2 (wahana kerjasama) terhadap Y2 (akses saprotan) sebesar 0,24 . Hal ini menunjukkan bahwa wahana kerjasama dan akses saprotan memiliki hubungan positif, jika wahana kerjasama mengalami kenaikan satu satuan maka akses saprotan akan mengalami peningkatan sebesar 0,24 atau $24 \%$. Hal ini menjawab hipotesis bahwa diduga terdapat pengaruh peran kelompok tani sebagai wahana kerjasama terhadap akses sarana produksi pertanian petani artinya Hipotesis 4 diterima. Peran kelompok tani dalam hal kerjasama bertujuan dalam mempermudah anggota dalam memenuhi kebutuhan dalam bidang pertanian baik dalam pemrosesan, pemasaran, pembelian, pemakaian alat-alat pertanian, kerjasama pelayanan, bank kerjasama, kerjasama usahatani dan kerjasa multi-tujuan (Anantanyu, 2011).

Nilai koefisien regresi unit produksi terhadap akses saprotan sebesar 0,22. Hal ini menunjukkan bahwa antara unit produksi dan akses saprotan memiliki hubungan positif, jika unit produksi mengalami kenaikan satu satuan maka akses saprotan akan mengalami peningkatan sebesar 0,22 atau $22 \%$. Hal ini menunjukkan bahwa terdapat pengaruh peran kelompok tani sebagai unit produksi terhadap akses sarana produksi pertanian petani. Berdasarkan hal tersebut pula maka Hipotesis 5 diterima. Peran kelompok tani sebagai unit produksi menuntut produksi anggota 
sebagai suatu kesatuan produksi.

Nilai koefisien regresi Y1 (perilaku petani) terhadap Y2 (akses saprotan) sebesar 0,11. Hal ini menunjukkan bahwa antara perilaku petani dengan akses saprotan memiliki hubungan positif, jika perilaku petani mengalami kenaikan satu satuan maka akses saprotan akan mengalami peningkatan sebesar 0,11 atau $11 \%$. Hal ini menunjukkan bahwa terdapat pengaruh perilaku petani terhadap akses sarana produksi pertanian petani atau Hipotesis 6 diterima. Meningkatnya perilaku petani tentunya menumbuhkan kesadaran oleh petani akan pentingnya ketersediaan sarana produksi pertanian seperti benih, pupuk dan obatobatan dalam menunjang produktivitas padi. Hal yang perlu dicermati selain terdapatnya pengaruh yang nyata dalam hubungan perilaku dengan akses saprotan adalah nilai korelasi yang hanya $11 \%$. Terdapat responden yang ternyata memiliki pengetahuan dan sikap bahwa penggunaan pupuk kimia dan pestisida nonalami kurang tepat jika terus dilanjutkan. Hal ini tentunya perlu mendapat perhatian bahwa budidaya secara kimiawi dapat meningkatkan produktivitas, namun penggunaan bahan kimia secara berlebihan akan merusak lingkungan dan penggunaan secara terus menerus akan menjauhkan dari lingkungan yang berkelanjutan (Cardoso dan James, 2012).

\section{Perilaku Petani dan Akses Saprotan dalam Mempengaruhi Penerapan PTT Padi}

Hasil analisis jalur dengan variabel perilaku petani dan akses saprotan sedangkan variabel dependen adalah akses saprotan menunjukkan hasil persamaan sebagai berikut :

$$
Y 3=3,00+0,14 Y 1+0,27 Y 2
$$

Melalui persamaan ini pula dapat menjawab beberapa hipotesis, antara lain :

$\mathrm{H} 7$ : diduga terdapat pengaruh perilaku petani terhadap penerapan PTT Padi

H8 : diduga terdapat pengaruh akses saprotan terhadap penerapan PTT Padi

Nilai koefisien regresi Y1 (perilaku petani) terhadap Y3 (penerapan PTT) sebesar 0,14. Hal ini menunjukkan bahwa antara perilaku petani dengan penerapan PTT memiliki hubungan positif, jika perilaku petani mengalami kenaikan satu satuan maka penerapan PTT akan mengalami peningkatan sebesar 0,14 atau $14 \%$. Hubungan positif ini menunjukkan bahwa terdapat pengaruh perilaku petani terhadap penerapan PTT Padi atau Hipotesis 7 diterima. Teori tindakan beralasan mengatakan bahwa seseorang akan melakukan suatu perbuatan apabila ia memandang perbuatan itu positif dan bila ia percaya bahwa orang lain ingin agar ia melakukannya. Teori tindakan berencana menambahkan bahwa selain kedua hal tersebut ada pertimbangan aspek kontrol yang dihayati. Hal ini berkaitan dengan pengalaman masa lalu dan perkiraan mengenai seberapa mudahnya perilaku tersebut dilaksanakan termasuk didalamnya akses sarana-prasarana (Ajen, 1988).

Nilai koefisien regresi Y2 (akses saprotan) terhadap Y3 (Penerapan PTT) sebesar 0,27. Hal ini menunjukkan bahwa akses saprotan dengan penerapan PTT memiliki hubungan positif, jika akses saprotan mengalami kenaikan satu satuan maka penerapan PTT akan mengalami peningkatan sebesar 0,27 atau $27 \%$. Hubungan ini menunjukkan bahwa terdapat pengaruh akses sarana produksi pertanian terhadap penerapan PTT Padi, atau Hipotesis 8 diterima.

\section{Perilaku Petani, Akses Saprotan dan Penerapan PTT Padi dalam Mempengaruhi Usahatani}

Hasil analisis jalur dengan variabel independen perilaku petani, akses saprotan dan penerapan PTT sedangkan variabel dependen adalah usaha tani menunjukkan hasil persamaan sebagai berikut :

$$
Y 4=9,34+0,45 Y 1+0,69 Y 2+0,70 Y 3
$$

Melalui persamaan ini dapat menjawab beberapa hipotesis, antara lain :

H9 : diduga terdapat pengaruh perilaku petani terhadap usahatani padi

H10 : diduga terdapat pengaruh akses sarana produksi pertanian terhadap usahatani padi

H11 : diduga terdapat pengaruh penerapan PTT Padi terhadap usahatani padi.

Nilai koefisien regresi Y1 (perilaku petani) terhadap Y4 (Usahatani Padi) sebesar 0,45. Hal ini mengandung pengertian bahwa antara perilaku petani dengan usahatani padi memiliki hubungan positif, jika perilaku petani mengalami kenaikan 
satu satuan maka usahatani akan mengalami peningkatan sebesar 0,45 atau $45 \%$. Hubungan ini menunjukkan bahwa terdapat pengaruh perilaku petani terhadap usahatani padi atau Hipotesis 9 diterima. Peningkatan perilaku petani berupa usahatani padi memiliki hubungan positif, jika akses saprotan mengalami kenaikan satu satuan maka usahaatani padi akan mengalami peningkatan sebesar 0,69 atau $69 \%$. Tingkat hubungan antara akses saprotan dengan usahatani

Tabel 2. Rerata Total Biaya Usahatani Padi Musim Tanam I dalam 0,3 ha

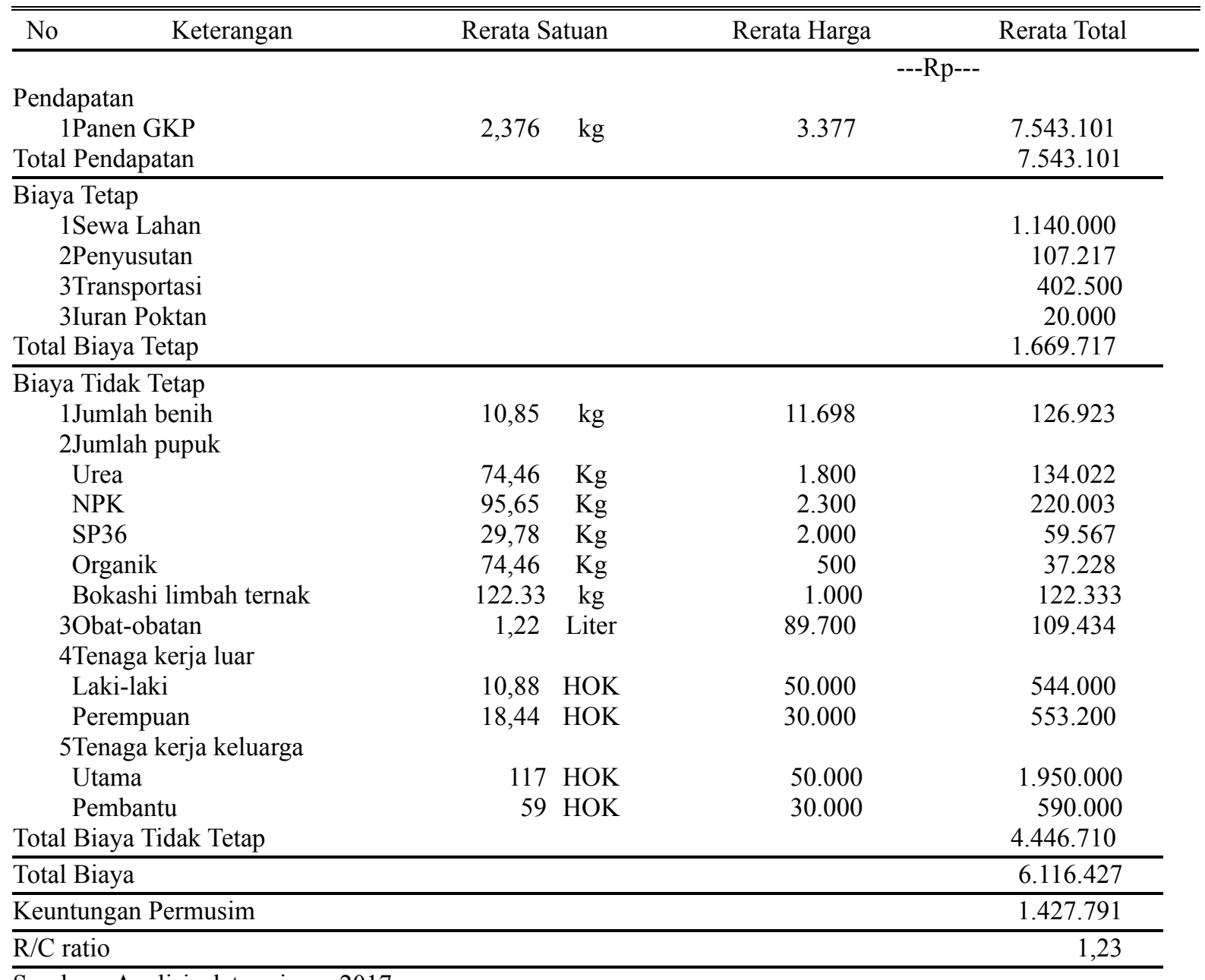

pengetahuan, sikap dan keterampilan merupakan tujuan penyuluhan. Pengetahuan, sikap dan keterampilan akan secara langsung mempengaruhi motivasi pengelolaan usahatani. Peningkatan perilaku ini akan memberikan dampak positif dalam usahataninya.

Nilai koefisien regresi Y2 (akses saprotan) terhadap Y4 (usahatani padi) sebesar 0,69 dengan tingkat siginfikasi sangat nyata. Hal ini menunjukkan bahwa akses saprotan dengan menunjukkan bahwa terdapat pengaruh akses sarana produksi pertanian terhadap usahatani padi atau Hipotesis 10 diterima. Ketersediaan sarana prasarana yang cukup dan akses yang mudah memberikan peningkatan manajemen dalam berusahatani. Untuk itulah kelompok tani perlu mendapat peningkatan kapasitas untuk membantu anggota dalam mengakses sarana-prasarana produksi pertanian.

Nilai koefisien regresi Y3 (penerapan PTT) 
terhadap Y4 (usahatani padi) sebesar 0,70. Hal ini menunjukkan bahwa penerapan PTT dengan usahatani padi memiliki hubungan positif, jika penerapan PTT mengalami kenaikan satu satuan maka usahatani padi akan mengalami peningkatan $70 \%$. Hasil analisis menunjukkan bahwa terdapat pengaruh penerapan PTT Padi terhadap usahatani padi, atau Hipotesis 11 diterima.

Pendekatan keuntungan usahatani dilihat dari sisi pemenuhan kebutuhan dalam hal ekonomis, keterjaminan bahwa usahataninya aman dari resiko kegagalan panen, keterjaminan bahwa modal usahataninya dapat diwariskan, dan usahatani tersebut merupakan identitas dalam kehidupan bermasyarakat (Suratiyah, 2015).

Peran berkelompok menjadi penting sebagai tempat petani berkumpul bersama demi memastikan bahwa usahataninya akan menghasilkan secara ekonomi, aman, berkelanjutan dan meningkatkan harga dirinya. Kelompok tani akan dapat membentuk petani dengan perilaku yang sesuai perkembangan dan juga memastikan bahwa sarana prasarananya terpenuhi.

Peran PTT sebagai sebuah filosofi dalam pemecahan permasalahan dalam berusahatani tentunya berperan dalam pemenuhan tersebut. PTT didasarkan pada empat prinsip antara lain PTT bukan merupakan teknologi maupun paket teknologi, tetapi merupakan suatu pendekatan agar sumber daya tanaman, lahan dan air dapat dikelola sebaik-baiknya; PTT memanfaatkan teknologi pertanian yang sudah dikembangkan dan diterapkan dengan memperhatikan unsur keterkaitan sinergis antar teknologi; PTT memperhatikan kesesuaian teknologi dengan lingkungan fisik maupun sosial-ekonomi petani; PTT bersifat partisipatif yang berarti petani turut serta menguji dan memilih teknologi yang sesuai dengan keadaan setempat dan kemampuan petani melalui proses pembelajaran (Abdulrachman et al., 2013).

\section{Analisis Usahatani Padi}

Rata-rata luas lahan yang diusahakan petani untuk usahatani padi adalah 0,30 hektar. Biaya penyusutan peralatan sebesar Rp 107.217 meliputi penyusutan cangkul, sabit, traktor, ember, terpal. Biaya iuran kelompok tani menyesuaikan pembelian urea petani. Biaya tidak tetap rata-rata untuk usahatani padi meliputi biaya benih, biaya pupuk, biaya obat-obatan dan biaya tenaga kerja yaitu sebesar $\mathrm{Rp}$ 1.784.377,-. Curahan tenaga kerja petani pemilik tidak termasuk dalam analisis usahatani. Dengan demikian biaya total rata-rata permusim yang dikeluarkan adalah sebesar $\mathrm{Rp}$ 1.917.210,-. Penerimaan rata-rata usahatani padi di Kecamatan Sale sebesar Rp 7.543,101,- dengan keuntungan 5.625.891,- permusim. Perhitungan ini dengan rerata luasan 0,30 ha.

Tabel 2 menunjukkan bahwa nilai $\mathrm{R} / \mathrm{C}$ rasio sebesar 1,23 . $\mathrm{R} / \mathrm{C}$ ratio merupakan salah satu cara untuk mengetahui perbandingan antara penerimaan dan biaya yang dikeluarkan. Selain itu $\mathrm{R} / \mathrm{C}$ rasio ini juga dilakukan untuk mengetahui efisiensi usahatani, yang dapat diketahui dari perbandingan antara total penerimaan dengan total biaya pada masing-masing usahatani. Hasil tersebut menunjukkan bahwa nilai $\mathrm{R} / \mathrm{C}>1$, maka usahatani tersebut dikatakan menguntungkan karena setiap satu rupiah biaya yang dikeluarkan akan menghasilkan penerimaan lebih besar dari satu rupiah. R/C rasio menunjukkan besarnya penerimaan untuk setiap rupiah biaya yang dikeluarkan dalam usahatani padi. Semakin tinggi nilai $\mathrm{R} / \mathrm{C}$, semakin menguntungkan dan efisien usahatani tersebut (Suratiyah, 2015).

\section{KESIMPULAN DAN SARAN}

\section{Kesimpulan}

Simpulan yang dapat diambil adalah peran kelompok tani sebagai kelas belajar, wahana kerjasama, dan unit produksi secara signifikan mempengaruhi perilaku petani. Peran kelompok tani sebagai wahana kerjasama, unit produksi dan perilaku petani secara signifikan mempengaruhi akses saprotan. Perilaku petani dan akses saprotan mempengaruhi secara signifikan terhadap penerapan PTT. Perilaku petani, akses saprotan dan penerapan PTT secara signifikan mempengaruhi usahatani petani. Dalam kondisi rerata, usahatani di Kecamatan Sale menguntungkan dari sisi ekonomi. Hal ini ditunjukkan dengan nilai $\mathrm{R} / \mathrm{C}$ yang tinggi.

Simpulan berikutnya adalah kelompok tani melalui perannya sebagai kelas belajar, wahana kerjasama, dan unit produksi pada ujungnya akan mempengaruhi usahatani anggotanya. Strategisnya posisi kelompok tani sebagai wadah untuk 
memberdayakan petani tercermin dalam hal tersebut. Menyikapi hal ini peningkatan kapasitas kelompok tani perlu kiranya mendapat perhatian

\section{Saran}

Pembinaan kelompok tani seharusnya mendapat perhatian lebih dan menjadi tolok ukur dalam penyaluran program kegiatan. Pembinaan kelompok tani yang berkesinambungan, memperhatikan segala aspek sumber daya lokal akan mampu memberikan dinamika kelompok yang lebih aktif. Dinamika kelompok inilah nantinya yang akan membentuk petani-petani yang memiliki perilaku baik pengetahuan, sikap dan keterampilan yang mampu bersaing.

\section{DAFTAR PUSTAKA}

Abdulrachman, S., M. J. Mejaya, P. Sasmita, dan A. Guswara. 2013. Pengelolaan Tanaman Terpadu (PTT) Padi Sawah Irigasi. Jakarta: Badan Penelitian dan Pengembangan Pertanian Kementerian Pertanian.

Ajen, I. 1988. Attitudes, Personality, and Behavior. Milton Keynes. Open University Press.

Akbar, A., dan M. Azizi. 2011. Participatory Management Opportunity for Optimizing in Agricultural Extension Education. Procedia Social and Behavioral Sciences 15. Elsevier B.V.: 1531-34.

Anantanyu, S. 2011. Kelembagaan Petani: Peran Dan Strategi Pengembangan Kapasitasnya. SEPA 7 (2): 102-9.

Ariola, M. M. 2006. Principles and Method of Research. Philipina: Rex Book Store, Inc.

Awais, M., dan N. Khan. 2014. Adoption of New Agricultural Technology: A Case Study of Buksa Tribal Farmers in Bijnor District, Western Uttar Pradesh, India. International Journal of Agriculture, Environment and Biotechnology 7 (2): 403.

BPS. 2015. Hasil Sensus Pertanian 2013 (Angka Tetap). In Berita Resmi Statistik, 2013:1-13.
Semarang. BPS Provinsi Jawa Tengah.

Cardoso, S. P., dan H. S. James. 2012. Ethical Frameworks and Farmer Participation in Controversial Farming Practices. Journal of Agricultural and Environmental Ethics 25 (3): $377-404$.

Ghozali, I., dan Fuad. 2008. Structural Equation Modeling. Semarang. Badan Penerbit Universitas Diponegoro.

Guo, M., X. Jia, J. Huang, K. B. Kumar, dan N. E. Burger. 2015. "Agriculture, Ecosystems and Environment Farmer Field School and Farmer Knowledge Acquisition in Rice Production: Experimental Evaluation in China." Agriculture, Ecosystems and Environment 209. Elsevier B.V.: 100-107.

Hamdi, A. S. dan E. Bahruddin. 2012. Metode Penelitian Kuantitatif Aplikasi dalam Pendidikan.Yogyakarta. Penerbit Deepublish

Hanudin, E., M. Nurudin, N. W. Yuwono, dan S. Handayani. 2003. "Klasifikasi Kesuburan Tanah Di Kecamatan Sumber, Bulu, Dan Sale Kabupaten Rembang." Rembang: Badan Pembangunan Daerah Kabupaten Rembang.

Hariadi, S. S. 2011. Dinamika Kelompok: Teori Dan Aplikasinya Untuk Analisis Keberhasilan Kelompok Tani Sebagai Unit Belajar, Kerjasama, Produksi, Dan Bisnis. Edited by Sekolah Pascasarjana Universitas Gadjah Mada. Yogyakarta. Sekolah Pascasarjana Universitas Gadjah Mada.

Hellin, J., M. Lundy, dan M. Meijer. 2009. Farmer Organization, Collective Action and Market Access in Meso-America. Food Policy 34 (1). Elsevier Ltd: 16-22.

Julius, A. 2015. Comparative Analysis of Cooperative and Non-Cooperative Farmers ' Access to Farm Inputs in Abuja, Nigeria. European Journal of Sustainable Developmaent 4 (1): 39-50. 
Ma, W., dan A. Abdulai. 2016. Does Cooperative Membership Improve Household Welfare? Evidence from Apple Farmers in China. Food Policy 58. Elsevier Ltd: 94-102.

Mawardi, M. 2016. Irigasi Asas Dan Praktek. Yogyakarta. Bursa Ilmu.

Nuryanti, S., dan D. K. S.Swastika. 2011. Peran Kelompoktani dalam Penerapan Teknologi Pertanian. orum Penelitian Agro Ekonomi 29 (70): 115-28.

Rashid, S. M. M., M. R. Islam, dan M. Quamruzzaman. 2016. Which Factor Contribute Most to Empower Farmers Through E-Agriculture in Bangladesh? Springer Plus 5 (1). Springer International Publishing: 1742. doi:10.1186/s40064-0163443-3.

Sarwono, J. 2007. Analisis Jalur Untuk Riset Bisnis Dengan SPSS. Yogyakarta: Penerbit
Andi.

Shah, Md.M.I., Grant, W.J., dan Stocklmayer, S. 2016. Farmer innovativeness and hybrid rice diffusion in Bangladesh. Technological Forecasting and Social Change. Elsevier Inc.

Suratiyah, K. 2015. Ilmu Usaha Tani. Jakarta: Penebar Swadaya.

Swastika, D. K. S., dan Hermanto. 2011. Penguatan Kelompok Tani: Langkah Awal Peningkatan Kesejahteraan Petani. Analisis Kebijakan Pertanian 9 (4): 371-90.

Syahyuti, S. Wahyuni, R. N. Suhaeti, A. K. Zakaria, dan T. Nurasa. 2014. Kajian Peran Organisasi Petani Dalam Mendukung Pembangunan Pertanian. Jakarta: Pusat Analisis Sosial Ekonomi dan Kebijakan Pertanian Badan Penelitian dan Pengembangan Pertanian. 